\title{
Responses of cows to abomasal infusion of lysine and methionine at two levels of dietary protein*
}

\author{
S.J. Mabjeesh ${ }^{1,4}$, E. Smoler', S. M. Abramson', I. Bruckental ${ }^{2}$, \\ S. Zamwel ${ }^{1}$, K. Nanjappan ${ }^{3}$ and A. Arieli ${ }^{1}$
}

\author{
'Department of Animal Sciences, The Faculty of Agricultural, \\ Food and Environmental Quality Sciences \\ P.O. Box 12, Rehovot 76100. Israel \\ ${ }^{2}$ Physiology and Nutrition Department, \\ Institute of Animal Sciences, Agriculture Research Organization. \\ The Volcani Center \\ Bet Dagan 50250, Israel \\ ${ }^{3}$ Department of Physiology, Veterinary College Research Institute \\ Namakkal, 637002, India
}

(Received 27 November 2001; revised version 27 February 2002; accepted 9 May 2002)

\begin{abstract}
The response in dairy cows fed high-concentrate diets to abomasal infusion of lysine (Lys) and methionine (Met) at two levels of dietary $\mathrm{CP}$ was examined. Four multiparous Israeli Hoistein cows (day in milk $=180 \pm 30$, means $\pm \mathrm{SE}$ ) were utilized in a $4 \times 4$ Latin square design experiment that included a $2 \times 2$ factorial arrangement with 18 -d periods. Cows were surgically prepared with abomasal cannulae and catheters implanted in the costoabdominal artery. Two diets were composed to contain high and low crude protein (CP) content ( $152 \mathrm{vs} 132 \mathrm{~g} / \mathrm{kg}$ dry matter). Abomasal infusion of either water or Lys $(38 \mathrm{~g} / \mathrm{d})$ plus Met $(14 \mathrm{~g} / \mathrm{d})$ was performed with each diet. On the last day of the experimental period the metabolism of amino acids (AA) across the mammary gland was monitored. Dry matter intakes and milk and protein yields were not affected by either dietary CP level or postruminal infusion of Lys plus Met and averaged 15.9,21.4, and $0.694 \mathrm{~kg} / \mathrm{d}$, respectively. Milk fat content and yield were not affected by dietary CP concentration, but did increase with abomasal infusion of Lys plus Met (33.3 vs $37.2 \mathrm{~g} / \mathrm{kg} ; \mathrm{P}<0.04$, and 0.703 vs $0.762 \mathrm{~kg} / \mathrm{d} ; \mathrm{P}<0.05$, respectively). Arterial plasma concentration of Lys and Met increased by 2.4- and 3.5-fold, respectively, when these AA were infused abomasally.
\end{abstract}

\footnotetext{
* Supported by a grant from the United States-Israel, Binational Agriculture Rescarch and Development Fund (BARD), No. US-2642-95

${ }^{4}$ Corresponding author
} 
Net mammary gland uptake of both AA increased during the abomasal infusion in the low CP diets but not in the high CP diets. The ratio of uptake across the udder of these AA to their corresponding output value in milk, suggested that there was no shortage of supplying Lys and Met from dietary intake. It was also apparent that increased uptake of Met across the udder was accompanied with higher fat secretion in milk.

KEY WORDS: dairy cows, milk production, amino acid, lysine, methionine

\section{INTRODUCTION}

Milk and milk protein yields can be influenced by dietary means, including increasing the crude protein $(\mathrm{CP})$ consumed by the cow. Such a response was achieved by increasing dietary $\mathrm{CP}$ up to $140 \mathrm{~g} / \mathrm{kg}$ dry matter (DM) relative to diets deficient in $\mathrm{CP}(90 \mathrm{~g} / \mathrm{kg} \mathrm{DM})$; however, further increases in dietary CP content often showed inconsistent responses (Clark and Davis, 1980). Increasing the supply of CP to the small intestine by adding undegradable protein (UDP) supplements increased milk and milk protein yields of cows maintained on protein-rich diets (Forster et al., 1983; McGuffey et al., 1990; Cunningham et al., 1996). Such an increase is unlikely to depend only on the supplementary $\mathrm{CP}$ in the diet; the quality and composition of the basic diets are also important. Predicting the quantity and profile of amino acids (AA) reaching the small intestine of dairy cows has been, and still is, equivocal in the current prediction systems of dairy cows (NRC, 1989). Nevertheless, efforts have been made to predict such AA profiles, in order to improve the balance and availability of AA such that requirements for milk protein secretion will be fulfilled (O'Connor et al., 1993). Consequently, limiting essential AA (EAA) are defined for milk protein synthesis under particular nutritional states.

Lys and Met are often considered to be co-limiting AA for milk protein synthesis, particularly when maize-based diets are fed to lactating dairy cows (Schwab et al., 1992a,b). Lys appears to be the first limiting AA when maize-based rations are supplemented with protein sources of maize origin, and Met may be first limiting when all, or most, of the UDP intake is supplemented by legume or animal byproducts, or both (Schwab et al., 1976; Rulquin, 1987). Most of the reported responses in milk and milk protein yiclds to infused Lys and Met have been in cows given diets prepared to be severely limiting in one or both AA (King et al., 1991; Guinard and Rulquin, 1994, 1995; Nichols et al., 1998). Indeed, other workers (Overton et al., 1998; Robinson et al., 1998) failed to observe any productive responses to supplementing diets with these AA where the ration had been better formulated to meet requirements of high-yielding dairy cows. This inconsistency in the productive response of dairy cows given extra EAA directly into the duodenum stresses the importance of the composted basic diets consumed by the animals. 
Besides the increasing interest in higher milk protein content, environmental concepts of $\mathrm{N}$ disposal in modern dairy farming emphasize the need for more precise information on supplementary protein and EAA in diets of dairy cows in accordance to requirements. Dairy cow rations in Israeli farming systems contain at least 650 to $700 \mathrm{~g} / \mathrm{kg}$ DM of a concentrate mixture with 300 to $350 \mathrm{~g} / \mathrm{kg} \mathrm{DM}$ of a roughage source which often consists of maize silage, legume or grass hay. Protected Lys and Met, in different commercial forms, are offered to farmers as a promising supplement to improve milk and milk protein production in high-yielding dairy cows. However, there is little information available on the addition of Lys and Met to rations that are high in concentrates and contain more than one source of $\mathrm{CP}$ in the diet. Therefore, the objective of this study was to investigate whether Lys and Met are limiting AA for milk and milk protein production in diets typically prepared on commercial farms in Israel. In this study, we combined continuous abomasal infusion of an AA mixture with diets that contained two levels of $\mathrm{CP}$ (high and low) relative to production requirements.

\section{MATERIAL AND METHODS}

\section{Diets}

Two diets with similar ingredients were prepared with two different levels of CP: one sufficient to meet cow requirements (NRC, 1989), referred here as high$\mathrm{CP}$, and one lower relative to CP allowances (low-CP; Table 1). Maize silage and wheat straw, comprising $330 \mathrm{~g} / \mathrm{kg} \mathrm{DM}$, served as the main sources of forage for both diets. All feedstuffs were incubated in the rumen using a standard in situ method described below. The in situ effective degradability values were used in linear programming software (Gavish, Giva't Brenner 60948, Israel) to compose the two diets. Complementary ingredients were calculated using a least-cost linear program (Gavish) to supply (per kg DM) $7.03 \mathrm{MJ}$ of net energy for lactation, neutral detergent fibre (NDF) $330 \mathrm{~g} / \mathrm{kg}$, acid detergent fibre (ADF) $214 \mathrm{~g}$, and CP $132 \mathrm{~g}$ in the low-CP diet, $255 \mathrm{~g} / \mathrm{kg}$ CP of this being UDP, CP $152 \mathrm{~g}$ in the high-CP diet, with $290 \mathrm{~g} / \mathrm{kg}$ of it UDP.

\section{Cows and experimental design}

Four Israeli-Holstein cows (live body weight $=560 \pm 37 \mathrm{~kg}$, day in milk $=180 \pm 30$, means \pm SE) were housed in a metabolic barn, each in individual pens. The cows were fitted with abomasal cannulae and arterial catheters. Cows were milked at 08.00 and 16.00 each day and milk yields were recorded. 
TABLE 1

Compositions of formulated diets given to dairy cows in this trial, $\mathrm{g} / \mathrm{kg}$ dry matter

\begin{tabular}{lcc}
\hline \multirow{2}{*}{ Item } & \multicolumn{2}{c}{ Diets } \\
\cline { 2 - 3 } & low crude protein & high crude protein \\
\hline Components & & \\
whole cottonseed & 231 & 213 \\
cracked maize grain & 223 & 206 \\
barley grain & 114 & 106 \\
maizc gluten meal & 15 & 57 \\
rapeseed meal & 30 & 28 \\
sunflower meal & 15 & 14 \\
vitamins and minerals & 44 & 47 \\
maize silage & 253 & 253 \\
wheat straw & 75 & 75 \\
& & \\
Chemical composition and nutritive value & & 647 \\
dry matter & 647 & 900 \\
organic matter & 902 & 491 \\
RDOM & 503 & 152 \\
crude protein & 132 & 290 \\
UDP & 255 & 330 \\
neutral detergent fibre & 336 & 206 \\
acid detergent fibre & 222 & 7.03 \\
net energy for lactation, $\mathrm{MJ} / \mathrm{kg}$ & 7.03 & \\
\hline
\end{tabular}

UDP, rumen undegradable crude protein; RDOM, rumen degradable organic matter, both determined in situ

$\dagger$ containing, per kg: vit. A $1.2 \mathrm{~g}$, vit. D $10 \mathrm{mg}$, vit. E $2.01 \mathrm{~g}, \mathrm{Mn} 11 \mathrm{mg}, \mathrm{Zn} 12 \mathrm{mg}, \mathrm{Fe} 4 \mathrm{mg}, \mathrm{I}_{2} 240 \mathrm{mg}$, $\mathrm{Co} 40 \mathrm{mg}$, Se $100 \mathrm{mg}, \mathrm{Cu} 800 \mathrm{mg},\left(\mathrm{NH}_{3}\right)_{2} \mathrm{SO}_{4} 1.4 \mathrm{mg}, \mathrm{MgSO}_{4} 1 \mathrm{mg}, \mathrm{Ca} 180 \mathrm{mg}, \mathrm{P} 90 \mathrm{mg}, \mathrm{NaCl} 90 \mathrm{mg}$

Two weeks prior to the experiment, cows were surgically implanted with an arterial catheter (i.d. $0.35 \mathrm{~mm}$, heparin-coated Teflon, T-10 X HN 6.0-35-90-M10S-PIG, COOK Inc., Bloomington, IN 47402-0489, USA), under local anaesthesia, into the dorsal aorta, via a costoabdominal artery following the method described by Haibel et al. (1989). Local anaesthesia was maintained by infiltrating a transverse line of lidocaine hydrochloride $(20 \mathrm{~g} / \mathrm{l}$, Xylocaine; Teva Medical Ltd, Ashdod 77100, Israel) into the subcutaneous tissue near the proximal border of each surgical site. A Teflon guide-wire (code 10 X TCMT-35-125-3-BH; COOK) technique was used to help insert the catheter in to the artery. A second temporary polyvinyl chloride catheter was inserted, $1 \mathrm{~d}$ before blood sampling, into a subcutaneous abdominal vein. Patency of catheters was maintained by daily flushing with sterile heparinized (300 i.u./ml) $154 \mathrm{mM} \mathrm{NaCl}$.

The cows were allowed to recover from the operations and were then used in a $4 \times 4$ Latin square experimental design with $2 \times 2$ factorial arrangement. Each ex- 
perimental period consisted of $14 \mathrm{~d}$ of adaptation and $4 \mathrm{~d}$ of sampling and collection. Continuous abomasal infusion of either $5 \mathrm{I}$ of $\mathrm{H}_{2} \mathrm{O}$ alone or with Lys plus Met (LM, 38 and $14 \mathrm{~g} / \mathrm{d}$ ) was utilized to form four dietary treatments: high $\mathrm{CP}_{-} \mathrm{H}_{2} \mathrm{O}$, high CP-LM, low CP- $\mathrm{H}_{2} \mathrm{O}$, and low CP-LM. The infusions were through a plastic tube, attached to the abomasal cannula, with a peristaltic pump (minipuls 2, GILSON, Villieres le Bel 95400, France).

\section{Experimental protocol}

Diets were prepared each morning, machine mixed, and were offered at 11.00 as a total mixed ration. Diets were adjusted to the refusals of the previous day to allow about $\sim 5 \%$ refusals. Each morning, refusals were removed from the feeders at 08.00 , collected and weighed. During the last $4 \mathrm{~d}$ of each experimental period, diets and refusals were sampled daily and stored at $-20^{\circ} \mathrm{C}$ for analysis. Milk samples were taken at each milking from d 15 to 17 of the experimental period and analyzed for fat, protein and lactose contents by infrared procedures (Milkoscan 605; Foss Electric, DK-3400 Hillerød, Denmark) at the Israeli Cattle Breeders Association Milk Recording Laboratory (Industrial Park, Caesarea 38900, Israel).

On d 15 to 17 of each experimental period, eight faecal grab samples were taken at 9-h intervals. The indigestible NDF (INDF) fraction was used to calculated the apparent total-tract digestibilities of nutrients. On the last day (d 18) of each period, cows were machine-milked at 08.00 , followed by hand stripping to remove any residual milk, at 09.00 , blood samples were collected. Blood samples were drawn concurrently from both the arterial and venous catheters at $60 \mathrm{~min}$ intervals into heparinized $(20 \mathrm{i} . \mathrm{u} . / \mathrm{ml})$ syringes over an 8 -h period. Cows were allowed to stand for $15 \mathrm{~min}$ prior to blood sampling to prevent any analytical bias that might exist as a result of blood flow fluctuations and to ensure steady-state conditions (Zeiler, 1961). Catheters were flushed between samplings with sterile heparinized ( 50 i.u. $/ \mathrm{ml})$ physiological saline $(154 \mathrm{mM} \mathrm{NaCl})$. Blood samples were immediately placed on ice and plasma was separated by centrifugation at $3000 \mathrm{~g}$ for $10 \mathrm{~min}$. Plasma was stored at $-20^{\circ} \mathrm{C}$ until analysis. At the end of sampling period, half udders of cows were milked separately as described earlier. Milk from the relevant half was sampled and stored appropriately for further analysis.

\section{In situ measurements}

For in situ incubations of feeds and faeces, polyester bags were suspended in the rumen in four replicates for each incubation time. Two dairy cows in mid-lactation with semi-permanent cannulae in the rumen were used for the in situ incubation. The cows were maintained on a standard diet with a 
roughage:concentrate ratio 35:65 and containing (per $\mathrm{kg} \mathrm{DM}$ ) $\mathrm{CP} 160 \mathrm{~g} \mathrm{CP}$, NDF 340 , and 7.11 MJ net energy for lactation.

Dry-milled samples $(5 \mathrm{~g})$ were weighed into $12 \times 6 \mathrm{~cm}$ polyester bags with a $45 \mu \mathrm{m}$ mean pore size. Bags were introduced serially into the rumen and incubated for $96,48,36,24,12,9,6$, or $3 \mathrm{~h}$. Solubility at $0 \mathrm{~h}$ was evaluated by immersing the bags for two consecutive 30 -min periods in warm water $\left(39^{\circ} \mathrm{C}\right)$. The rumenincubated polyester bags were removed together, immediately rinsed with cold tap water and washed in a washing machine with cold water for $45 \mathrm{~min}$ without spinning.

\section{Chemical analyses and calculations}

Feed DM was determined by drying at $105^{\circ} \mathrm{C}$ for $24 \mathrm{~h}$. Diets, refusals, silage and faeces were dried at $55^{\circ} \mathrm{C}$ for $48 \mathrm{~h}$. All dried samples were ground to pass through a $2-\mathrm{mm}$ mesh sieve and pooled on a DM basis. The concentrations of organic matter $(\mathrm{OM}), \mathrm{NDF}$ and $\mathrm{CP}(6.25 \times \mathrm{N})$ were measured for all dried pooled samples. Total $\mathrm{CP}(6.38 \times \mathrm{N})$ in milk on the last day of the experimental period, blood-sampling day, was measured in fresh samples.

The concentration of INDF in the diets (corrected for refusals) and faeces was used to calculate the apparent digestibilities of the dietary components - DM, OM, NDF and CP. For the INDF determination, $5 \mathrm{~g}$ samples of dry and pooled faeces, diets, and refusals were weighed into $12 \times 6 \mathrm{~cm}$ polyester bags. Each sample was incubated in duplicate in the rumen of two ruminally cannulated dairy cows maintained on a standard diet as described earlier. Bags were removed from the rumen after $168 \mathrm{~h}$ and machine-washed with cold water. Dry matter content of residuals was determined as described earlier. Residuals from the same sample were pooled and ground to pass a $1-\mathrm{mm}$ sieve. The NDF fraction was measured according to the method of Van Soest et al. (1991) and was assumed to represent INDF.

Effective ruminal degradabilities of the different feed fractions were calculated according to Ørskov and McDonald (1979) using a fractional passage rate of $6.5 \% / \mathrm{h}$. Plasma urea $\mathrm{N}$ concentration was determined according to Coulomb and Faverau (1963) on pooled $8 \mathrm{~h}$ samples.

Whole milk samples $(0.5 \mathrm{ml})$ and a similar volume of an L-norleucine standard were added and then hydrolyzed in $4 \mathrm{M} \mathrm{HCl}(3 \mathrm{ml})$ at $110^{\circ} \mathrm{C}$ for $18 \mathrm{~h}$ for AA analysis.

For plasma free AA analysis, $100 \mathrm{ml}$ of sulphosalicylic acid $(50 \mathrm{~g} / 100 \mathrm{~g})$ was added to $900 \mathrm{ml}$ plasma and total protein was precipitated by centrifuging at $15100 \mathrm{~g}$ for 5 min at $4^{\circ} \mathrm{C}$ (model 12-24 centrifuge; Mikro, D-78532 Hettich, Germany). AA were separated on a reverse-phase column (Superpher $60 \mathrm{RP} 8,4 \mu \mathrm{m}$, LiChro Cartridge 250-4; Merck, D-64271 Darmstadt, Germany) by HPLC after derivatizing with 9-fluorenylmethyloxycarbonyl chloride. AA concentration was measured on pooled $8 \mathrm{~h}$ samples. 
AA net fractional extraction by the mammary gland was calculated as the arteriovenous (AV) concentration difference, and expressed as percentage of the arterial concentration. Plasma flow was calculated according to the method described by Cant et al. (1993) using the Fick principle and Phe and Tyr as internal markers. Whole milk Phe and Tyr concentrations, corrected for $4 \%$ of milk protein AA derived from non-mammary synthesized protein appearing in the milk (Whitney et al., 1976), were used in the model instead of casein-bound and milk-free Phe and Tyr. Net uptake of individual AA by the gland was calculated as the AV concentration difference $\times$ mammary plasma flow. Amino acid balance across the mammary gland was calculated as uptake by the mammary gland divided by AA secreted in milk, corrected for milk protein AA derived from non-mammary synthesized protein (Whitney et al., 1976). Plasma flow and balance calculations were performed over the $8 \mathrm{~h}$ sampling period for the udder half in which the venous catheter was implanted.

\section{Statistical analyses}

Data were analyzed using the General Linear Model procedure of SAS (1985). The $4 \times 4$ Latin square design included a $2 \times 2$ factorial arrangement of treatments. A single degree of freedom and orthogonal comparisons were used to determine the effects of dietary CP levels (high vs low), abomasal infusion $\left(\mathrm{H}_{2} \mathrm{O}\right.$ vs $\mathrm{LM}$ ) and their interaction. Means were considered significantly different at $\mathrm{P}<0.05$. Results are presented as Lsmeans \pm SEM.

\section{RESULTS}

Intakes, digestibilities, milk yield and composition

Nutrient intakes and digestibilities are listed in Table 2. Intakes of DM and OM were similar among treatments, averaging 15.9 and $14.4 \mathrm{~kg} / \mathrm{d}$, respectively. However, $\mathrm{CP}$ intake differed between low-CP and high-CP treatments with $\mathrm{CP}$ content in the ration being 2.01 and $2.50 \mathrm{~kg} / \mathrm{d}$, respectively. Apparent total-tract digestibility of CP was similar for all treatments, averaging $684 \mathrm{~g} / \mathrm{kg}$. However, DM and OM digestibilities were significantly higher in the high-CP diets and were not affected by LM infusion. Digestibility of high-CP diets averaged 700 and $726 \mathrm{~g} / \mathrm{kg}$ for DM and $\mathrm{OM}, 630$ and $675 \mathrm{~g} / \mathrm{kg}$ for low-CP diets, respectively. This enhancement in digestibility coefficients of nutrients in ruminant diets is a result of improving the ruminal utilizing efficiency of N (Oldham, 1984; Argyle and Baldwin, 1989).

Milk production was similar among treatments, averaging $21.4 \mathrm{~kg} / \mathrm{d}$ (Table 3 ). Likewise, milk protein and lactose contents and yields were similar across dietary 
TABLE 2

Daily intake and apparent total-tract digestibility of feed for dairy cows given diets with high or low crude protein ( 152 and $132 \mathrm{~g} / \mathrm{kg}$ ) coupled with abomasal infusion of $5 \mathrm{l} / \mathrm{d}$ containing $\mathrm{H}_{2} \mathrm{O}$ or lysine $38 \mathrm{~g}$ plus methionine $14 \mathrm{~g}$

\begin{tabular}{|c|c|c|c|c|c|c|}
\hline \multirow{3}{*}{ Item } & \multicolumn{4}{|c|}{ Diets } & \multirow{3}{*}{$\mathrm{SE}$} & \multirow{3}{*}{$\frac{\text { Effect of level, } \mathrm{P}<}{\text { crude protein }}$} \\
\hline & \multicolumn{2}{|c|}{ low crude protein } & \multicolumn{2}{|c|}{ high crude protein } & & \\
\hline & $\mathrm{H}_{2} \mathrm{O}$ & LM & $\mathrm{H}_{2} \mathrm{O}$ & LM & & \\
\hline \multicolumn{7}{|l|}{ Intake, $\mathrm{kg}$} \\
\hline dry matter & 15.9 & 15.2 & 16.4 & 16.2 & 0.69 & NS \\
\hline organic matter & 14.6 & 13.6 & 14.7 & 14.5 & 0.62 & NS \\
\hline crude protein & 2.10 & 2.01 & 2.49 & 2.46 & 0.09 & 0.01 \\
\hline \multicolumn{7}{|c|}{ Digestibility coefficient } \\
\hline dry matter & 0.62 & 0.64 & 0.70 & 0.70 & 0.03 & 0.05 \\
\hline organic matter & 0.68 & 0.67 & 0.73 & 0.73 & 0.01 & 0.05 \\
\hline crude protein & 0.71 & 0.69 & 0.67 & 0.67 & 0.01 & NS \\
\hline
\end{tabular}

LM, Lys plus Met infusion

$\dagger$ NS, not significant; there was no significant effect of LM infusion or interactive effect

TABLE 3

Daily milk production and composition of dairy cows given diets with high or low crude protein (152 and $132 \mathrm{~g} / \mathrm{kg}$ ) coupled with abomasal infusion of $5 \mathrm{l} / \mathrm{d}$ containing $\mathrm{H}_{2} \mathrm{O}$ or lysine $38 \mathrm{~g}$ plus methionine $14 \mathrm{~g}$

\begin{tabular}{|c|c|c|c|c|c|c|}
\hline \multirow{3}{*}{ Item } & \multicolumn{4}{|c|}{ Diets } & \multirow{3}{*}{$\mathrm{SE}$} & \multirow{3}{*}{$\frac{\text { Effect of level, } P<\frac{1}{\mathrm{~L}}}{\mathrm{LM}}$} \\
\hline & \multicolumn{2}{|c|}{ low crude protein } & \multicolumn{2}{|c|}{ high crude protein } & & \\
\hline & $\mathrm{H}_{2} \mathrm{O}$ & LM & $\mathrm{H}_{2} \mathrm{O}$ & $\mathrm{LM}$ & & \\
\hline Milk, kg/d & 21.2 & 20.9 & 22.2 & 21.2 & 1.02 & NS \\
\hline \multicolumn{7}{|c|}{ Milk protein } \\
\hline $\mathrm{g} / \mathrm{kg}$ & 32.8 & 33.4 & 31.9 & 34.5 & 0.7 & NS \\
\hline $\mathrm{kg} / \mathrm{d}$ & 0.688 & 0.687 & 0.698 & 0.703 & 0.04 & NS \\
\hline \multicolumn{7}{|l|}{ Milk fat } \\
\hline $\mathrm{g} / \mathrm{kg}$ & 34.6 & 38.9 & 31.9 & 35.5 & 0.15 & 0.04 \\
\hline $\mathrm{kg} / \mathrm{d}$ & 0.727 & 0.789 & 0.679 & 0.734 & 0.03 & 0.05 \\
\hline \multicolumn{7}{|c|}{ Milk lactose } \\
\hline $\mathrm{g} / \mathrm{kg}$ & 42.2 & 42.6 & 43.0 & 41.8 & 0.11 & NS \\
\hline $\mathrm{kg} / \mathrm{d}$ & 0.895 & 0.894 & 0.989 & 0.886 & 0.06 & NS \\
\hline
\end{tabular}

LM, Lys plus Me1 infusion

$\dagger$ NS, not significant; there was no significant effect of dietary crude protein level or interactive effect 
treatments and averaged 33.2 and $42.4 \mathrm{~g} / \mathrm{kg}$, and 0.694 and $0.916 \mathrm{~kg} / \mathrm{d}$, respectively. However, fat content was higher $(\mathrm{P}<0.04)$ with $\mathrm{LM}$ infusion in both high- and low-CP diets, averaging 37.2 and $33.3 \mathrm{~g} / \mathrm{kg}$ for $\mathrm{LM}$ and $\mathrm{H}_{2} \mathrm{O}$ infusion, respectively. Consequently, milk fat yield was higher with $\mathrm{LM}$ vs $\mathrm{H}_{2} \mathrm{O}$ infusion $(0.762$ vs $0.702 \mathrm{~kg} / \mathrm{d})$.

Plasma urea $N$ and arterial $A A$ concentrations, and metabolism across the mammary gland

Plasma urea $\mathrm{N}$ concentration was significantly higher in the high-CP vs low-CP diets averaging 16.8 and $12.2 \mathrm{mM}$, respectively (Table 4). Arterial plasma AA concentrations was similar between treatments and was not affected by either abomasal infusion or dietary CP concentration (Table 4). Met concentration increased by 3.5 - and 2.4-fold in the low-CP and high-CP diets with LM infusion, respectively. Lys concentration decreased as a result of higher $\mathrm{CP}$ concentration in the diet and increased during LM infusion, being 2.19- and 1.25-fold higher in the low-CP and high-CP treatments, respectively, which resulted in an interactive effect on plasma concentration.

TABLE 4 Concentration of amino acids $(\mu \mathrm{M})$ and urea $\mathrm{N}(\mathrm{mM})$ in the arterial plasma of dairy cows given diets with high or low crude protein ( 152 and $132 \mathrm{~g} / \mathrm{kg}$ ) coupled with abomasal infusion of $5 \mathrm{l} / \mathrm{d}$ containing $\mathrm{H}_{2} \mathrm{O}$ or lysine $38 \mathrm{~g}$ plus methionine $14 \mathrm{~g}$

\begin{tabular}{|c|c|c|c|c|c|c|c|c|}
\hline \multirow{3}{*}{ Amino acid } & \multicolumn{4}{|c|}{ Diets } & \multirow{3}{*}{ SE } & \multirow{2}{*}{\multicolumn{3}{|c|}{ Effect of level, $P<\dagger$}} \\
\hline & \multicolumn{2}{|c|}{ low crude protein } & \multicolumn{2}{|c|}{ high crude protein } & & & & \\
\hline & $\mathrm{H}_{2} \mathrm{O}$ & LM & $\mathrm{H}_{2} \mathrm{O}$ & LM & & $\mathrm{CP}$ & $\mathrm{LM}$ & $\mathrm{CP} \times \mathrm{LM}$ \\
\hline Thr & 80.8 & 75.1 & 101.3 & 77.7 & 7.20 & NS & NS & NS \\
\hline Arg & 88.3 & 98.1 & 94.3 & 106.5 & 7.30 & NS & NS & NS \\
\hline Ala & 299.8 & 297.1 & 244.2 & 218.9 & 67.2 & NS & NS & NS \\
\hline Tyr & 58.7 & 70.2 & 68.4 & 60.0 & 6.56 & NS & NS & NS \\
\hline Pro & 77.0 & 101.0 & 96.4 & 90.0 & 12.8 & NS & NS & NS \\
\hline Met & 19.5 & 67.3 & 25.1 & 53.6 & 5.06 & NS & 0.001 & NS \\
\hline Val & 185.2 & 221.4 & 200.7 & 187.5 & 24.6 & NS & NS & NS \\
\hline Phe & 47.4 & 63.3 & 44.2 & 41.5 & 9.51 & NS & NS & NS \\
\hline Ilc & 85.3 & 95.3 & 90.2 & 74.5 & 13.5 & NS & NS & NS \\
\hline Leu & 156.3 & 183.7 & 218.7 & 205.7 & 22.6 & NS & NS & NS \\
\hline His & 38.7 & 52.9 & 44.6 & 35.1 & 11.8 & NS & NS & NS \\
\hline Lys & 86.3 & 188.9 & 95.7 & 120.3 & 11.7 & 0.01 & 0.002 & 0.02 \\
\hline Plasma urea $\mathrm{N}$ & 11.7 & 12.6 & 17.3 & 16.3 & 0.65 & 0.01 & NS & NS \\
\hline
\end{tabular}

LM, Lys plus Met infusion; CP, protein content in diet $\dagger N S$, not significant 
Net fractional extractions of plasma AA by the udder are shown in Table 5. Net fractional extraction of non-EAA was similar for all treatments and ranged from $15.1 \%$ for Pro to $35.3 \%$ for Val. Branched-chain AA exhibited higher fractional extraction rates and averaged 56,35 and $36 \%$ for Leu, Ile and Val, respectively. Arg extraction decreased by $25 \%$ with LM infusion. Net fractional extraction of Met and Lys was influenced by LM infusion and that of Lys by dietary CP content, being higher in the low-CP vs the high-CP diets. Abomasal LM infusion considerably decreased the net fractional extraction of plasma Met by $\sim 100 \%$ and Lys by $78 \%$.

TABLE 5

Net fractional extraction of amino acids by the half udder of dairy cows given diets with high or low crude protein ( 152 and $132 \mathrm{~g} / \mathrm{kg}$ ) coupled with abomasal infusion of $5 \mathrm{l} / \mathrm{d}$ containing $\mathrm{H}_{2} \mathrm{O}$ or lysine $38 \mathrm{~g}$ plus methionine $14 \mathrm{~g}$ (values are expressed as $100 \times$ arteriovenous difference / arterial concentration)

\begin{tabular}{|c|c|c|c|c|c|c|c|}
\hline \multirow{3}{*}{ Amino acid } & \multicolumn{4}{|c|}{ Diets } & \multirow{3}{*}{ SE } & \multirow{2}{*}{\multicolumn{2}{|c|}{ Effect of level, $\mathrm{P}<\dagger$}} \\
\hline & \multicolumn{2}{|c|}{ low crude protein } & \multicolumn{2}{|c|}{ high crude protein } & & & \\
\hline & $\mathrm{H}_{2} \mathrm{O}$ & LM & $\mathrm{H}_{2} \mathrm{O}$ & $\mathrm{LM}$ & & $\mathrm{CP}$ & LM \\
\hline Thr & 36.8 & 35.2 & 38.8 & 35.4 & 2.58 & NS & NS \\
\hline Arg & 57.4 & 46.3 & 51.2 & 40.4 & 2.93 & NS & 0.01 \\
\hline Ala & 33.7 & 33.5 & 40.6 & 33.5 & 2.74 & NS & NS \\
\hline Tyr & 23.4 & 18.8 & 22.0 & 26.8 & 2.90 & NS & NS \\
\hline Pro & 13.6 & 13.5 & 12.9 & 20.2 & 3.86 & NS & NS \\
\hline Met & 55.1 & 33.3 & 51.0 & 19.5 & 4.09 & NS & 0.001 \\
\hline Val & 36.7 & 39.2 & 32.3 & 32.4 & 4.10 & NS & NS \\
\hline Phe & 48.8 & 59.3 & 58.9 & 60.9 & 3.83 & NS & NS \\
\hline Ile & 36.0 & 34.0 & 34.1 & 34.1 & 1.06 & NS & NS \\
\hline Leu & 55.3 & 54.0 & 54.8 & 57.7 & 2.87 & NS & NS \\
\hline His & 36.4 & 54.2 & 42.5 & 46.3 & 9.37 & NS & NS \\
\hline Lys & 57.4 & 34.4 & 51.2 & 26.8 & 3.46 & 0.002 & 0.001 \\
\hline
\end{tabular}

LM, Lys plus Met infusion; CP, protein content in diet, there was no interactive effect $\dagger$ NS, not significant

Net uptakes of all AA were similar among treatments with the exception of Met and Lys (Table 6). Met and Lys had higher uptakes in the low-CP vs high-CP diets ( $6.8 \mathrm{vs} 4.3 \mathrm{mmol} / \mathrm{h}$ and $24.8 \mathrm{vs} 15.1 \mathrm{mmol} / \mathrm{h}$, respectively). Met uptake was doubled during LM infusion in the low-CP diets whereas it decreased by $19.5 \%$ in the high-CP diets. Lys net uptake across the mammary gland was not affected by LM infusion in both CP levels. Plasma flow calculated from the Fick principle was similar across treatments and averaged $358 \mathrm{l} / \mathrm{h}$ and $402 \mathrm{l} / \mathrm{l}$ milk (Table 6).

The AA balance ratio of EAA in general was equal or exceeded unity for all dietary treatments and was not affected by either LM infusion or CP consumption (Table 7). However, Lys balance across the gland was influenced by diet CP con- 
TABLE 6

Net uptake (mmol/h) of amino acids and plasma flow $(\mathrm{l} / \mathrm{h})$ across the half udder of dairy cows given diets with high or low crude protein (152 and $132 \mathrm{~g} / \mathrm{kg}$ ) coupled with abomasal infusion of $5 \mathrm{l} / \mathrm{d}$ containing $\mathrm{H}_{2} \mathrm{O}$ or lysine $38 \mathrm{~g}$ plus methionine $14 \mathrm{~g}$

\begin{tabular}{|c|c|c|c|c|c|c|c|c|}
\hline \multirow{3}{*}{ Amino acid } & \multicolumn{4}{|c|}{ Diets } & \multirow{3}{*}{ SE } & \multirow{2}{*}{\multicolumn{3}{|c|}{ Effect of level, $P<\dagger$}} \\
\hline & \multicolumn{2}{|c|}{ low crude protein } & \multicolumn{2}{|c|}{ high crude protein } & & & & \\
\hline & $\mathrm{H}_{2} \mathrm{O}$ & $\mathrm{LM}$ & $\mathrm{H}_{2} \mathrm{O}$ & LM & & $\mathrm{CP}$ & LM & $\mathrm{CP} \times \mathrm{LM}$ \\
\hline Thr & 12.8 & 11.3 & 13.9 & 10.1 & 1.61 & NS & NS & NS \\
\hline Arg & 22.1 & 19.8 & 17.6 & 15.8 & 2.72 & NS & NS & NS \\
\hline Ala & 40.7 & 44.2 & 37.8 & 27.1 & 10.7 & NS & NS & NS \\
\hline Tyr & 5.8 & 5.4 & 5.5 & 5.9 & 0.61 & NS & NS & NS \\
\hline Pro & 4.3 & 6.6 & 4.5 & 6.7 & 1.81 & NS & NS & NS \\
\hline Met & 4.5 & 9.0 & 4.8 & 3.8 & 0.68 & 0.01 & 0.04 & 0.01 \\
\hline Val & 28.5 & 43.3 & 24.3 & 22.3 & 10.8 & NS & NS & NS \\
\hline Phe & 9.4 & 9.7 & 9.6 & 9.3 & 0.61 & NS & NS & NS \\
\hline Ile & 13.1 & 14.6 & 11.7 & 9.4 & 2.91 & NS & NS & NS \\
\hline Leu & 37.4 & 45.0 & 44.4 & 43.2 & 8.60 & NS & NS & NS \\
\hline His & 6.1 & 10.9 & 6.5 & 6.1 & 2.33 & NS & NS & NS \\
\hline Lys & 21.6 & 27.9 & 18.3 & 11.8 & 2.94 & 0.02 & NS & NS \\
\hline \multicolumn{9}{|l|}{ Plasma flow } \\
\hline $\mathrm{l} / \mathrm{h}$ & 368 & 384 & 352 & 329 & 37.6 & NS & NS & NS \\
\hline l/l milk & 424 & 434 & 381 & 370 & 40.1 & NS & NS & NS \\
\hline
\end{tabular}

LM, Lys plus Met infusion; CP. protein content in diet + NS, not significant

tent, being higher for the low-CP than the high-CP diet. Lysine balance across the gland was affected from the $\mathrm{CP}$ level and the $\mathrm{LM} \times \mathrm{CP}$ level interaction. The $\mathrm{LM}$ infusion caused an apparent increase of 96 and $23 \%$ in the balance ratio of Met and Lys, respectively, in the low-CP diets and a decrease of 19 and $37 \%$, respectively, in the high-CP diet resulting in a significant interaction effect of LM infusion by dietary $\mathrm{CP}$ for Met ratio. The balance ratio for Met did differ from unity within all treatments except for that in the LM-low-CP diet where it was significantly higher than unity. However, Lys balance ratio was equal to unity in both the high- and low$\mathrm{CP}$ diets with $\mathrm{H}_{2} \mathrm{O}$ treatment and significantly higher than unity in the LM low-CP and lower than unity in the high-CP diets with the LM infusion (Table 7).

\section{DISCUSSION}

This study was conducted to examine the effect of abomasal infusion of Lys plus Met on the production of milk and milk components in rations prepared to be 
TABLE 7

Balance ratio of amino acid uptake to milk output in udder of dairy cows given diets with high or low crude protein ( 152 and $132 \mathrm{~g} / \mathrm{kg}$ ) coupled with abomasal infusion of $5 \mathrm{l} / \mathrm{d}$ containing $\mathrm{H}_{2} \mathrm{O}$ or lysine $38 \mathrm{~g}$ plus methionine $14 \mathrm{~g}$

\begin{tabular}{|c|c|c|c|c|c|c|c|c|}
\hline \multirow{3}{*}{ Amino acid } & \multicolumn{4}{|c|}{ Diets } & \multirow{3}{*}{ SE } & \multirow{2}{*}{\multicolumn{3}{|c|}{ Effect of level, $P<\dagger$}} \\
\hline & \multicolumn{2}{|c|}{ low crude protcin } & \multicolumn{2}{|c|}{ high crude protein } & & & & \\
\hline & $\mathrm{H}_{2} \mathrm{O}$ & $\mathrm{LM}$ & $\mathrm{H}_{2} \mathrm{O}$ & $L M$ & & $\mathrm{CP}$ & LM & $\mathrm{CP} \times \mathrm{LM}$ \\
\hline Thr & 1.05 & 0.91 & 1.17 & 0.83 & 0.15 & NS & NS & NS \\
\hline Arg & $2.58^{\ddagger}$ & $2.20^{*}$ & $2.01^{*}$ & $1.87^{\ddagger}$ & 0.30 & NS & NS & NS \\
\hline Ala & $2.38^{\ddagger}$ & $2.39^{\ddagger}$ & $2.17^{\ddagger}$ & $1.60^{\ddagger}$ & 0.59 & NS & NS & NS \\
\hline Tyr. & 1.21 & 1.10 & 1.14 & 1.27 & 0.13 & NS & NS & NS \\
\hline Pro & $0.20^{\ddagger}$ & $0.28^{\ddagger}$ & $0.22^{\ddagger}$ & $0.29^{\ddagger}$ & 0.08 & NS & NS & NS \\
\hline Met & 1.05 & $2.06^{*}$ & 1.08 & 0.87 & 0.18 & 0.02 & NS & 0.02 \\
\hline Val & $2.24^{\dagger}$ & $3.10^{\ddagger}$ & $1.91^{\ddagger}$ & $1.81^{\frac{i}{z}}$ & 0.69 & NS & NS & NS \\
\hline Phe & 1.14 & 1.24 & 1.16 & 1.15 & 0.10 & NS & NS & NS \\
\hline Ile & 1.70 & 1.77 & 1.47 & 1.27 & 0.32 & NS & NS & NS \\
\hline Leu & $2.08^{\ddagger}$ & $2.31^{+}$ & $2.36^{\ddagger}$ & $2.44^{*}$ & 0.42 & NS & NS & NS \\
\hline His & 1.67 & 2.62 & 1.60 & 1.55 & 0.49 & NS & NS & NS \\
\hline Lys & 1.24 & $1.52^{\ddagger}$ & 1.03 & $0.65^{\ddagger}$ & 0.18 & 0.03 & NS & NS \\
\hline
\end{tabular}

LM, Lys plus Met infusion: CP, protein content in dict

$\dagger$ NS, nol significant

${ }^{\ddagger} \mathrm{P}<0.05$ when $\mu \neq 1$ within treatment

high in concentrates. Two levels of dietary $\mathrm{CP}$ were chosen, with a relatively low level of UDP (NRC, 1989), in order to magnify the effect of LM supplementation in diets.

Milk and milk protein production were not affected by abomasal LM infusion despite the fact that plasma Lys and Met concentrations were drastically increased. Production responses to added AA, especially ruminally protected Met plus Lys, have been reported when added to diets of dairy cow in early, mid and late lactation (Xu et al., 1998). This increase was related to milk casein content in all stages of lactation. Milk protein content increased when ruminally protected Lys plus Met were added to dairy cow diets ( 57 days in milk) based on maize-distillers grains (Nichols et al., 1998). Others reported that Met, unlike Lys, limits milk and milk protein production when added to dairy cows diets (Armentano et al., 1997; Robinson et al., 1998). Those responses were achieved when rations contained $500 \mathrm{~g} / \mathrm{kg}$ (on a DM basis) roughage and a concentrate mixture based on soyabean proteins, or were composed to be deficient in metabolic allowances of one or both of these EAA. In the current study, however, diets contained a higher content of concentrates.

The availability of precursors, such as AA, from blood plasma may provide a better explanation for the unresponsiveness of cows fed the high-CP diet and re- 
ceiving the LM infusion. Plasma AA concentrations were similar for high-CP and low-CP diets except for Lys, which was lower in the high-CP diets. The higher CP content in the high-CP diet was achieved by increasing the content of maize gluten meal, which is highly undegradable in the rumen (NRC, 1989). Maize gluten meal is relatively poor in Lys (NRC, 1996), which would explain the lower plasma Lys concentration. In the low-CP diets, the increase in the plasma concentration of Met and Lys during LM infusion was much greater than that in the high-CP diets, resulting in an interaction effect of dietary CP concentration by LM infusion. This suggests that in the high-CP diets, as a result of greater amounts of absorbed $\mathrm{CP}$, larger plasma pools of AA occurred. Larger plasma fluxes of Phe, Met and Lys were observed when Phe or Lys plus Met were infused intravenously into dairy goats at different stages of lactation (Bequette et al., 1999; Mabjeesh et al., 2000). Despite the apparent evidence of more EAA absorbed in the high-CP diets and during LM infusion, milk production was similar among treatments, raising the question of the metabolic fate of these AA at the mammary gland and whole body levels.

Plasma flow measured in this study might be over estimated because certain amount of Phe and Tyr (up to $11 \%$ for Phe and $25 \%$ for Tyr; Bequette et al., 1999) might be taken up across the mammary gland as plasma-circulating peptides. In order to compare uptake of EAA across the mammary gland, however, it was assumed that the experimental accuracy was similar for all treatment. The plasma flow and the ratio of plasma flow per milk volume measured in the present study compare well with other reported values measured by dye dilution method (Metcalf ct al., 1991) or the Fick principle with Phe+Tyr (Mabjeesh et al., 1999). Overall, the uptake and balance ratio of EAA across the mammary gland were adequate for milk protein secretion in both the high-CP and low-CP diets. Net fractional extraction of Arg was decreased during the LM infusion in both the low-CP and high-CP diets, which suggests a transporter competition at the level of the mammary gland. Both Lys and Arg share the same specific transport system ( $\mathrm{Y}+$ ) in bovine mammary gland and have been found to be strong competitors of each other's uptake into bovine mammary tissue (Baumrucker, 1984). Net fractional extraction of Met decreased upon LM infusion in the low-CP diet and net uptake was almost doubled, resulting in a higher balance ratio without altering protein secretion, but increasing fat production and content in milk. Met could supply S for the de novo mammary synthesis of Cys via a trans-sulphuration pathway. This contribution, however, might be small in the mammary gland (Lee et al., 1997). Met is essential for de novo synthesis of short-chain $\left(\mathrm{C}_{4}\right.$ to $\left.\mathrm{C}_{14}\right)$ fatty acids in the mammary gland (Varvikko et al., 1999). Hence higher milk fat secretion in the present study might occur at the level of mammary tissue via this metabolic route in the low-CP diet when LM was infused. However, in the high-CP diet the net uptake of Met at the mammary gland was decreased and still milk fat secretion was elevated. It has been thought that shortage of Met may limit the formation of apoprotein associated with lipoproteins, 
resulting in reducing the synthesis of lipoproteins and subsequent transport of triglycerides from the liver toward peripheral tissues, particularly the mammary gland (Pullen et al., 1989). In the current study the fatty acid profile secreted in milk was not measured, hence the precise pathway in which Met elevated milk fat secretion could not be clarified in the high- and low-CP diets. However, it may be speculated that milk fat secretion was increased as a result of increased supply to both the mammary gland (e.g., in the low-CP LM diet) and liver (e.g., high-CP LM diet). Similar results were observed when plasma Met concentration was increased during abomasal infusion of LM or LM plus His in dairy cows fed grass-silage-based diets (Vanhatalo et al., 1999; Varvikko et al., 1999). Lys uptake and balance ratios were higher in the low-CP compared to high-CP diets regardless of the LM infusion without any alteration in protein secretion. The balance ratios across the gland in the high-CP diets during LM infusion decreased for Met and Lys, however the ratio was similar to unity for Met and less than unity for Lys. This result for Lys might be explained by several reasons. In the current study, uptake was calculated from free plasma AA concentrations alone and the peptide-bound AA that might contribute to the mammary tissue metabolism was not considered. Up to $16 \%$ of Lys secretion in milk was contributed from plasma peptides in lactating goats at different stages of lactation (Bequette et al., 1996; Mabjeesh et al., 2000). Interestingly, this fraction was not affected by the availability of free Lys in plasma. Hence, if this fraction is considered in the current study then Lys supply to milk protein synthesis would not limit milk production. A second point that might affect the balance ratio measurements is the fact that plasma concentration and not whole blood values were used. During LM infusion, erythrocytes might serve as a carrier for AA, supplying Lys to the mammary gland. Indeed, Hanigan et al. (1991) showed, in dairy cows, that the uptake of AA (including Met and Lys) by the mammary gland differs between whole blood and plasma pools. Erythrocyte and plasma exchanges were also found to occur and plasma uptake therefore may inadequately represents whole blood uptake. A third point that should be borne in mind that these balance measurements across the mammary gland were done under the assumption that AA are taken up by the gland and contribute to a biosynthetic pathway (anabolism). The oxidative pathway was activated in the mammary gland of goats when surplus EAA (e.g., Leu, Lys), relative to requirements, were supplied intravenously (Bequette et al., 1996; Mabjeesh et al., 2000). Up to $31 \%$ of the Lys taken up by the gland during LM infusion was oxidized (Mabjeesh et al., 2000). This mechanism may be a disposal route for excess AA taken up by the gland. If this pathway were to be taken as general for other EAA, the balance ratio would fall beyond unity and these measurements would have to be reconsidered with respect to classifying limiting EAA for protein synthesis. The exact metabolic fate of the extra Lys and Met taken up by the gland remains to be clarified; nonetheless, it is apparent that on excess of these EAA might be disposed of via the oxidative path- 
way, at the level of either the mammary or liver tissue (Mabjeesh et al., 1999). Indeed, plasma urea $\mathrm{N}$ concentrations were higher for high- $\mathrm{CP}$ diets suggesting that there was increased deamination and oxidation of dietary AA.

\section{CONCLUSIONS}

In this study we show that diets containing high concentrations of grains are adequate to supply AA to the mammary gland of dairy cows and fulfill metabolic requirements. Abomasal infusion of Lys plus Met caused a dramatic increase in the blood plasma concentration of these AA without any effect on milk protein secretion. It was suggested that an increased supply of Met might cause higher fat secretion by the mammary gland. It was concluded that excess ingested AA are catabolized in the high-CP diets and upon LM infusion.

\section{REFERENCES}

Aldrich J.M., Muller L.D., Varga G.A., 1993. Nonstructural carbohydrates and protein effects on rumen fermentation, nutrients flow, and performance of dairy cows. J. Dairy Sci. 72, 1091-1105

Argyle J.L., Baldwin R.L., 1989. Effects of amino acids and peptides on rumen microbial growth yields. J. Dairy Sci. 72, 2017-2027

Armentano L.E., Bertics S.J., Ducharme G.A., 1997. Response of lactating cows to methionine or methionine plus lysine added to high protein diets based on alfalfa and heated soybeans. J. Dairy Sci. 80, 1194-1239

Backwell F.R.C., Bequette B.J., Wilson D., Calder A.G., Metcalf J.A., Wray-Cahen D., MacRae J.C., Beever D.E., Lobley G.E., 1994. Utilisation of dipeptides by the caprine mammary gland for milk protein synthesis. Amer. J. Physiol. 267, R1-R6

Baumrucker C.R., 1984. Cationic amino acid transport by bovine mammary tissue. J. Dairy Sci. 67 , 2500-2506

Bequette B.J., Backwell F.R.C., Crompton L.A., 1998. Current concepts of amino acid and protein metabolism in the mammary gland of the lactating ruminant. J. Dairy Sci. 81, 2540-2559

Bequette B.J., Backwell F.C.R., Kyle C.E., Calder A.G., Buchan V., Crompton L.A., France L.A., MacRae J.C., 1999. Vascular sources of phenylalanine, tyrosine, lysine, and methionine for casein synthesis in lactating goats. J. Dairy Sci. 82, 362-377

Bequette B.J., Backwell F.C.R., MacRae J.C., Lobley G.E., Crompton L.A., Metcalf J.A., Sutton J.D., 1996. Effect of intravenous amino acid infusion on lcucine oxidation across the mammary gland of the lactating goat. J. Dairy Sci. 79, 2217-2224

Bertics S.J., Grummer R.R., 1999. Effects of fat and methionine hydroxy analog on prevention or alleviation of fatty liver induced by feed restriction. J. Dairy Sci. 82, 2731-2736

Cant J.P.. DePeters E.J., Baldwin R.L., 1993. Mammary amino acid utilization in dairy cows fed fat and its relationship to milk protein depression. J. Dairy Sci. 76, 762-774

Chancy A.L., Marbach E.P., 1962. Modified reagent for determination of urea and ammonia. Clin. Chem. 8, 130 
Clark J.H., Davis C.L., 1980. Some aspects of feeding high producing dairy cows. J. Dairy Sci. 76, 873-885

Cornell Net Protein and Carbohydrate System (CNCPS): A Manual for Using the Cornell Net Protein and Carbohydrate System for Evaluating Cattie Diets, 1994. Revised for CNCPS release 3. Cornell University, Ithaca, NY

Coulomb J.J., Faverau L., 1963. A simple semi-micro method for calorimetric determination of urea. Clin. Chem. 9, 102-108

Cunningham K.D., Cecava M.J., Johnson T.R., Ludden P.A., 1996. Influence of source and amount of dietary protein on milk yield by cows in early lactation. J. Dairy Sci. 79, 620-630

Feng P., Hoover W.H., Miller T.K., Blauwiekel R., 1993. Interactions of fiber and nonstructural carbohydrates on lactation and ruminal function. J. Dairy Sci. 76, 1324-1333

Forster R.J., Grieve D.G., Buchanan-Smith J.G., Macleod G.K., 1983. Effect of dietary protein degradability on cows in early lactation. J. Dairy Sci. 66, 1653-1662

Guinard J., Rulquin H., 1994. Effects of graded amounts of duodenal infusions of lysine on the mammary uptake of major milk precursors in dairy cows. J. Dairy Sci. 77, 3565-3576

Guinard J., Rulquin H., 1995. Effect of graded amounts of duodenal infusions of methionine on the mammary uptake of major milk precursors in dairy cows. J. Dairy Sci. 78, 2196-2207

Haibel G.K., Guilbault L.A., Villeneuve P., Thatcher W.W., 1989. Aortic catherterization in cattle via the costoabdominal artery and validation for progesterone and estradiol- $17 \beta$ sample coliection. Amer. J. Vet. Res. 50, 1923-1925

Hanigan M.D., Calvert C.C., DePeters E.J., Reis B.L., Baldwin R.L., 1991. Whole blood and plasma amino acid uptakes by lactating bovine mammary glands. J. Dairy Sci. 74, 2484-2490

Kennedy P.M., Milligan L.P., 1980. The degradation and utilization of endogenous urea in the gastrointestinal tract of ruminants: a review. Can. J. Anim. Sci. 60, 205-221

King K.J., Bergen W.G., Sniffen C.J., Grant A.L., Grieve D.B., King V.L., Ames N.K., 1991. An assessment of absorbable lysine requirements in lactating cows. J. Dairy Sci. 74, 2530-2539

Lee J., Treloar B.P., Sinclair B.R., Prosser C.P., Davis S.R., Harris P.M., 1997. Utilization of methionine by the mammary gland of lactating goat. Proc. NZ Soc. Anim. Prod. 56, 547-563

Mabjeesh S.J., Bruckental I., Arieli A., 1999. Heat-treated whole cottonseed: effect of dietary protein concentration on the performance and amino acid utilization by the mammary gland of dairy cows. J. Dairy Res. 66, 9-22

Mabjeesh S.J., Kyle C.E., MacRae J.C., Bequette B.J., 2000. Lysine metabolism by the mammary gland of lactating goats at two stages of lactation. J. Dairy Sci. 83, 996-1003

McGuffey R.K., Green H.B., Basson R.P., 1990. Lactation responses of dairy cows receiving bovine somatotropin and fed rations varying in crude protein and undegradable intake protein. J. Dairy Sci. $73,2437-2443$

Meijer G.A.L., de Jonge L.H., Breuer M., Van der Meulen J., Van Vuuren A.M., 1997. Peptide bound amino acids in arterial and mammary venous plasma of high yielding diary cows. J. Dairy Sci. 80 , Suppl.1, 154 (Abstr.)

Metcalf J.A., Sutton J.D., Cockburn J.E., Napper D.J., Beever D.E., 1991. The influence of insulin and amino acid supply on amino acid uptake by the lactating bovine mammary gland. J. Dairy Sci. 74, 3412-3420

National Research Council, 1989. Nutrient Requirements of Dairy Cattle. 6th revised Edition. Natl. Acad. Sci., Washington, DC

National Research Council, 1996. Nutrient Requirements of Beef Cattle. 7th revised Edition. Natl. Acad. Sci., Washington, DC

Nichols J.R., Schingoethe D.J., Maiga H.A., Brouk M.J., Piepenbrink M.S., 1998. Evaluation of corn distillers grains and ruminally protected lysine and methionine for lactating dairy cows. J. Dairy Sci. 81, 482-491 
Nocek J.E., Russell J.B., 1988. Protein and energy as an integrated system. Relationship of ruminal protein and carbohydrate availability to microbial synthesis and milk production. J. Dairy Sci. $71,2070-2107$

Oldham J.D., 1984. Protein-energy interrelationships in dairy cows. J. Dairy Sci. 67, 1090-1114

Ørskov E.R., McDonald I., 1979. The estimation of protein degradability in the rumen from incubation measurements weighted according to the rate of passage. J. Agr. Sci. 92, 499-499

Overton T.R., Cameron M.R., Elliott J.P., Clark J.H., Nelson D.R., 1995. Ruminal fermentation and passage of nutrients to the duodenum of lactating cows fed mixtures of corn and barley. J. Dairy Sci. 78, 1981-1998

Overton T.R., Emmert L.S., Clark J.H., 1998. Effects of source of carbohydrate and protein and rumen-protected methionine on performance of cows. J. Dairy Sci. 81, 221-228

Parker D.S., Lomax M.A., Seal C.J., Wilton J.C., 1995. Metabolic implications of ammonia production in the ruminant. Proc. Nutr. Soc. 54, 549-563

Pullen D.L., Palmquist D.L., Emery R.S., 1989. Effect on days of lactation and methionine hydroxy analog on incorporation of plasma fatty acids into plasma triglycerides. J. Dairy Sci. 72, 49-58

Robinson P.H., Chalupa W., Sniffen C.J., Julien W.E., Sato H., Watanabe K., Fujieda T., Suzuki H., 1998. Ruminally protected lysine or lysine and methionine for lactating dairy cows fed a ration designed to meet requirements for microbial and postruminal protein. J. Dairy Sci. 81, 1364-1373

Rulquin H., 1987. The determination of certain limiting amino acids in the dairy cow by post-ruminal administration. Reprod. Nutr. Develop. 27, 299-300

Rulquin H., Pisulewski P.M., Vérité R., Guinard J., 1993. Milk production and composition as a function of postruminal lysine and methionine supply: a nutrient-response approach. Livest. Prod. Sci. 37, 69-90

Satter L.D., Slyter L.L., 1974. Effect of ammonia concentration on rumen microbial protein production in vitro. Brit. J. Nutr. 32, 199-208

Schwab C.G., Bozak C.K., Whitehouse N.L., 1992. Amino acid and flow to duodenum at four stages of lactation. 1. Sequence of lysine and methionine limitation. J. Dairy Sci. 75, 3486-3502

Schwab C.G., Bozak C.K., Whitehouse N.L., Oslon V.M., 1992. Amino acid and flow to duodenum at four stages of lactation. 2. Extent of lysine and methionine limitation. J. Dairy Sci. 75, 35033518

Schwab C.G., Satter L.D., Clay B., 1976. Response to lactating dairy cows to abomasal infusion of amino acids. J. Dairy Sci. 59, 1254-1270

Shabi Z., Bruckental I., Zamwell S., Tagari T., Arieli A., 1999. Effects of extrusion of grain and feeding frequency on rumen fermentation, nutrient digestibility, and milk yield and composition in dairy cows. J. Dairy Sci. 82, 1252-1263

Shennan D.B., Millar I.D., Calvert D.T., 1997. Mammary-tissue amino acid transport systems. Proc. Nutr. Soc. 56, 177-191

Statistical Analysis Systems Institute, 1985. SAS User's Guide: Statistics. Statistical Analysis Systems Institute Inc., Cary, NC

Vanhatalo A., Huhtanen P., Toivonen V., Varvikko T., 1999. Response of dairy cows fed grass silage diets to abomasal infusions of histidine alone or in combinations with methionine and lysine. J. Dairy Sci. 82, 2674-2685

Van Soest, P.J., Robertson J.B., Lewis B.A., 1991. Methods for dietary fiber, neutral detergent fiber, and nonstarch polysaccharides in relation to animal nutrition. J. Dairy Sci. 74, 3583-3597

Varvikko T., Vanhatalo A., Jalava T., Huhtanen P., 1999. Lactation and metabolic responses to graded abomasal doses of methionine and lysine in cows fed grass silage diets. J. Dairy Sci. 82, 2659-2673

Weigel D.J., Elliott J.P., Clark J.H., 1997. Effects of amount and ruminal degradability of protein on nutrient digestibility and production by cows fed tallow. J. Dairy Sci. 80, 1150-1159 
Whitney R. Mcl., Brunner K.E., Ebner K.E. Jr., Josephson R.V., Morr C.V., Swaisgood H. E., 1976. Nomenclature of the proteins of cow's milk: fourth revision. J. Dairy Sci. 59, 795-815

Xu C., Wensing T., Beynen A.C., 1998. Effects of high calcium intake on fat digestion and bile acid excretion in feces of veal calves. J. Dairy Sci. 81, $2173-2177$

Zeiler K.L., 1961. Theory of the use of arteriovenous concentration differences for measuring metabolism in steady and non-steady states. J. Clin. Invest. 40, 2111-2125

\section{STRESZCZENIE}

\section{Reakcja krów otrzymujących dawki o różnej zawartości bialka na infuzję lizyny i metioniny do trawieńca}

Doświadczenie przeprowadzono na 4 krowach - wieloródkach, holsztynach izraelskich (w $180 \pm 30$ dniu laktacji), w układzie kwadratu łacińskiego $4 \times 4$, zawierającym układ $2 \times 2$ czynnikowy z 18 -to dniowymi okresami. Krowy miały założone kaniule do trawieńca oraz katetery do tętnicy żebrowobrzusznej. Skarmiano dwie dawki o wysokiej lub niskiej zawartości białka ogólnego ( $152 \mathrm{vs} 132 \mathrm{~g} / \mathrm{kg}$ s.m.). Przy podawaniu każdej z dawek infundowano do trawieńca wodę lub lizynę (Lys) $38 \mathrm{~g} / \mathrm{dzień}$ z metioniną (Met) $14 \mathrm{~g} /$ dzicń. W ostatnim dniu okresu doświadczalnego oznaczano metabolizm aminokwasów (aa) w gruczole mlekowym.

Pobranie s.m. paszy oraz wydajność mleka i białka w mleku nie zależały ani od zawartości białka $w$ dawce ani od infuzji Lys+Met i wynosiły średnio 15,9;21,4 i 0,694 kg/dzien, odpowiednio. Podobnie, zawartość i wydajność tłuszczu mleka nie zależały od ilości białka w dawce, lecz wzrastały po infuzji Lys+Met (odpowicdnio, 33,3 vs 37,2 g/kg; P $<0,04$, oraz 0,703 vs 0,762 kg/dzień; $\mathbf{p}<0,05$ ). Stężenie Lys i Met w plazmie krwi tętniczej wzrosło 2,4- i 3,5-cio krotnie, odpowiednio po infuzji tych aa do trawicńca. Pobranic netto obydwóch aa przez gruczoł mlekowy zwiększało się podczas ich infuzji do trawieńca, gdy krowy otrzymywały dawkę o niskicj zawartości białka, czego nie stwierdzono przy podawaniu dawki wysokobiałkowej. Stosunek pobrania tych aa przez gruczol mlekowy do odpowiadających im wartościom wydalanym w mleku sugeruje, że pobierane dawki nie były niedoborowe pod względem zawartości Lys i Met. Wydaje się także, że zwiększeniu pobrania Met przez gruczoł mlekowy towarzyszyło zwiększenie produkcji łłuszczu mleka. 